\title{
How Boards of Directors Can Contribute to Governing IT
}

\author{
Laura Caluwe \\ Antwerp Management School, University of \\ Antwerp, Antwerp, Belgium \\ Laura.caluwe@uantwerpen.be \\ Carla Wilkin, \\ Monash Business School, Monash University, \\ Victoria, Australia \\ Carla.wilkin@monash.edu
}

\begin{abstract}
Digital transformation is becoming ubiquitous as organizations increasingly rely on IT to create business value. As a result, IT strategy is increasingly intertwined with organizational strategy, with risks as IT becomes progressively more important, requiring both management and governance. Given boards of directors are ultimately accountable for strategic decision-making and control, these changes charge boards with accountability for governing digital assets. Whilst board-level IT governance should enable better organizational performance, research suggests that the value created by the board in governing IT depends on the roles they play. In exploring these roles, we use the more mature research domain of corporate governance to develop improved understanding of the type of board roles and the importance assigned by a board to governing IT.
\end{abstract}

\section{Introduction}

In the last two decades there has been specific focus on information technology (IT) governance, in part as a consequence of IT's centrality in facilitating enterprise risk management and also in generating value in digitized organizations [1-3]. Herein IT governance is regarded as being "an integral part of corporate governance for which the board is accountable. It involves the definition and implementation of processes, structures and relational mechanisms that enable both business and IT stakeholders to execute their responsibilities in support of business/IT alignment, and the creation and protection of IT business value" [4, p. 3].

\author{
Steven De Haes \\ Antwerp Management School, University of \\ Antwerp, Antwerp, Belgium \\ Steven.dehaes@ams.ac.be \\ Tim Huygh \\ Open Universiteit, Heerlen, The Netherlands, \\ Antwerp Management School, Antwerp, Belgium, \\ tim.huygh@ou.nl
}

As a consequence, researchers have increasingly called for greater engagement of boards of directors in IT governance [5], with empirical evidence showing that board-level IT governance enables improved organizational performance [6-9]. In this regard the governance style of boards is shown to have a moderating effect $[6,10]$. With the role of boards chiefly defined in terms of 'monitoring' and 'advising' [11-13], the value created in governing IT is dependent on boards' enactment of these functions. Whilst prior studies have explored the role of boards of directors in corporate governance, there is a lack of research specifically addressing their role in governing IT. In response, this study uses the more mature research domain of corporate governance to inform literature on board-level IT governance by addressing the following research questions:

RQ1: What role should boards play in governing IT? RQ2: How can boards implement IT governance roles?

The remainder of the paper is structured as follows. Section 2 details the theoretical background, including discussion about the constructs of corporate governance and board-level IT governance, with a specific focus on the roles of a board of directors. Section 3 describes the research approach, and in Section 4 we report the results which are discussed in Section 5. Then, in Section 6, we outline implications for theory and practice, with limitations and directions for future research outlined in Section 7. Finally, in Section 8 we conclude the paper.

\section{Theoretical background}

\subsection{The board of directors and corporate governance}


The board of directors, commonly referred to as 'the board', is the formal body constituted to oversee all activities in an organization, with a key role in the system of rules and practices by which an organization is controlled and directed. This system, referred to as 'corporate governance', "involves a set of relationships between a company's management, its board, its shareholders and other stakeholders. Corporate governance also provides the structure through which the objectives of the company are set, and the means of attaining those objectives and monitoring performance are determined" [14].

Given the focus of corporate governance is upon interaction between boards and senior organizational executives, it is unsurprising that the literature on corporate governance is characterized by a dominant focus on agency theory. Implicit in this is the focus on the role of a board of directors regarding controls [15, 16]. In accord with agency theory, in the context of separation of ownership and control, conflicts may arise due to differing levels of risk appetite and differing interests [17] between the two key actors, namely: the principal, who is the task-assigning actor, and an agent who is the task-executing actor. In its role related to corporate governance, a board should control for the self-interest of executive management (the agent) while protecting stakeholder (principal) interests [18]. However, this dualistic perspective is challenged as being inadequate in capturing all the complexity of the board's task [15, 16]. In arguing for greater theoretical pluralism, prior research posits that rather than replacing agency by another dominant theory, differing theoretical perspectives should coexist, thereby offering complementary views to explain different board phenomena. Such alternative theories include the resource based view of the firm, resource dependence theory and stewardship theory [19].

\subsection{Board-level IT governance}

IT governance, as an integral part of corporate governance [4], implicitly establishes a role for the board of directors with a range of research and practitioner sources supporting this perspective. For example, Shleifer and Vishny [20, p. 737] define corporate governance as "the ways in which suppliers of finance to corporations assure themselves of getting a return on investment". Their definition emphasizes the creation of value from investments, which correlates with reference to investments being part of defining IT governance i.e., "in support of (...) the creation and protection of business value from ITenabled business investments" [4, p.3]. Further, corporate governance regulatory requirements, such as the Sarbanes-Oxley Act (SOX), oblige organizations to report on the effectiveness of their internal control systems. As IT is increasingly an essential component of internal control systems [21], IT becomes inevitably linked to corporate governance. This is explicitly articulated by the International Standards for the Professional Practice of Internal Auditing, when it states that "the internal audit activity must assess whether the information technology governance of the organization supports the organization's strategies and objectives" [22, p.13]. Similarly, South Africa's code of company governance (King IV) identifies "technology and information governance" as one of the functional areas of company governance [23].

These assumptions and/or requirements for IT governance imply board involvement through linkages with corporate governance. In this regard, two research streams suggest that IT governance exists at the managerial-level and at the level of the board of directors [9], with the latter addressing the board involvement in IT-related strategic decision-making and control $[8,24]$. This involvement is increasingly imperative as digitized organizations face serious IT risk-related consequences due to: cyber security [25]; the evolving reliance on big data [26]; and blockchain [27]. For example, in 2018, the global average total cost of data breaches (related to share price, reputation and litigation) exceeded USD \$3.86 million, while organizations who contain a breach in less than 30 days are estimated to save more than USD \$1 million [28]. The organizational implications of such IT-related exposures suggest an urgency for boards' increased engagement with IT governance for the direction and control of their organizations' digital assets [29].

Given the linkage between corporate and IT governance, and the fact that digital transformation is a key contributing factor to organization's growing complexity [30], we argue that board-level IT governance research is in need of theoretical pluralism and consideration of different board roles.

\section{Research approach}

In exploring the role of boards of directors in governing IT, we first seek to clarify understanding about corporate governance, with a specific focus on the role played by boards. To ensure rigor in our review of the corporate governance literature, we sought a framework by which to guide this review. Accordingly we adopted the framework by Huse [19], who builds on the seminal work of Zahra and Pearce [31], and integrates this with the fragmented research 
published subsequently. Huse's framework combines various theories and perspectives, which offers the theoretical pluralism needed to identify the various roles of the board in governing IT. It constitutes an established, comprehensive and detailed overview of six different roles for a board of directors. These roles are framed in terms of: (1) behavioral control; (2) advice and counsel; (3) output control; (4) networking, lobbying, legitimating, and communication; (5) strategic control; and (6) strategic participation [19].

Next, based on the IT governance literature that (at least partially) focuses on board-level or director-level matters, we sought to use a specific sample of IT governance research in order to scope how these six roles may be equated with IT governance roles. This analysis involved a review of 32 board-level IT governance papers, which were identified by Caluwe and De Haes [5], with the addition of 8 papers, published after their review.

To identify the presence, frequency and centrality of concepts in this literature, we used qualitative content analysis [32]. Based on our data set of boardlevel IT governance papers, this approach allowed us to describe different board roles related to IT governance. Specifically, by drawing on board roles as identified in the corporate governance literature to articulate this framework of six board roles, we created a coding frame to guide our content analysis. This frame comprises a description, an overview of related theories, a list of what should constitute specific board tasks, an explanation of the value created, an overview of the ways in which the board roles can be implemented and a list of key words describing each board role.

The outcome from this manually executed content analysis of our 40 identified papers is conceptualization of the roles of the board with regard to IT governance. Specifically, we derived an overview of how each of the six board roles can relate to executing IT governance. This analysis includes identification of related and relevant theories, specific board tasks, an explanation of the value created by each role and their possible implementation. These findings enable formulation of answers to both of our research questions.

\section{Results}

\subsection{Board roles in IT governance}

In this section, we briefly describe each role of the board in corporate governance and then outline what this means in the context of IT governance.

4.1.1 Behavioral control. In general, the board's role in behavioral control, otherwise referred to as the board's monitoring function [16, 33], focuses on its function regarding management behavior and operational control [19]. This control is performed by scrutinizing, evaluating and regulating the actions of executive management $[13,18]$.

With regard to IT, boards are responsible for monitoring/controlling managerial IT-related decisions and actions [7, 34, 35]. In doing so, rather than judging specific management decisions, boards should focus on how executives handle decision-making and evaluate whether they have established the correct procedures to adequately manage IT [36]. Specifically, this role requires boards to ensure that IT risks are identified and addressed [37], to identify and monitor IT performance objectives [7, 38], and to hire and fire a CIO [34, 39]. Consistent with corporate governance research findings, IT governance research draws on agency theory to explain the board's behavioral control role $[8,34,40]$. Instances where boards should protect the organization and its stakeholders against the selfinterested behavior of management include ensuring that a manager does not make large IT investment for the purpose of gaining his/her increased power by enlarging the IT department [34] rather than for organizational needs.

Ineffective IT investment behavior, which is induced by management's self-interested behavior, may be avoided by effective board governance $[8,10$, 34]. Further, increased board oversight of risk management offers the potential to improve risk mitigation [41, 42] and avoid costly lawsuits [43]. Specifically, boards' IT-related behavioral control is shown to positively influence the maturity of IT risk management practices [44]. Thus, through behavioral control, shareholder value is created [42, 45], by lowering the cost of capital [42], and/or regaining shareholders' trust after operational IT failures [34, 41].

4.1.2 Advice and counsel. With respect to advice and counsel, boards, based on their directors' expertise and experience $[13,46]$, play a key advisory role in providing advice and feedback that informs and counsels the CEO and executive management $[12,16$, 18]. This role reflects aspects of stewardship theory, wherein managers are considered trustworthy stewards of the organization. Thus, the role advocates boards 
supporting management rather than monitoring them to control self-interest $[16,47]$. Further, research that uses resource dependence theory to investigate this role shows that directors' competencies may be valuable resources $[18,48]$.

In the context of IT governance, boards should offer IT-related guidance and advice to management $[6,34]$. Resource dependence theory [34, 49] and stewardship theory [8, 44] are also applied in IT governance literature. From a resource dependency perspective, directors with IT experience should add value to an organization through their IT-related expertise, such as knowledge related to governing IT and IT outsourcing [8, 49, 50]. Stewardship theory suggests that rather than controlling managers, boards should offer advice and direction, such as indicating potential IT strategies and risks [8].

Other examples of specific tasks related to this role include creating an atmosphere of joint accountability concerning IT resources and stimulating collaboration between the $\mathrm{CIO}$ and executive management [6]. In general, this advice and counsel role facilitates social alignment by promoting trust between the board and executives [10], and by supporting shared understanding of how IT can add business value through innovation and growth [51]. Further, board members should enable a better fit between the needs of the organization and the external environment [8], and address risks of IT resource deficiencies [34] by directing the attention of management and enhancing the quality of their decisions.

4.1.3 Output control. Since a board's output controls primarily relate to organizational outputs such as corporate social responsibility and outputs in financial markets [19], as with behavioral control, it involves monitoring executive management, but with an external focus. In accord with stakeholder theory, this focus concerns the board's responsibility for protecting the interests not only of shareholders, but also of other stakeholders such as employees, the local community and the environment [52]. Advocates of this role suggest that the application of agency theory be broadened to include these various stakeholders as principals rather than concentrating solely on an organization's shareholders $[52,53]$.

A major element of board output control is oversight of financial reporting. As this depends heavily on IT, it is surprising that very few references to this board responsibility are evident in our selected set of IT governance papers. In this regard, Butler and Butler [54] mention that the responsibility of the audit committee with respect to IT relates to its responsibilities for financial reporting. The stakeholder-oriented aspect of the output control role is referenced briefly in the board-level IT governance literature. Herein, a specific task concerns ensuring adequate reporting on IT-related matters to all stakeholders [54]. Again, stakeholder theory is relevant, as it is the board's duty to monitor management concerning IT-related issues in order to safeguard the interests of all stakeholders [55].

4.1.4 Networking, lobbying, legitimating, communication. Boards act as boundary spanners between the organization and its environment [12, 18], The networking, lobbying, legitimating and communication role of the board are elements of its service role, with a specific focus on the external environment [19]. Theoretical grounding for this role is evident in resource dependence theory $[12,16,18]$, as it advocates that "the organization's need for resources makes it potentially dependent on the external sources of these resources" i.e., its environment [56, p. xii]. The essence of this role resides in the board's relational (also termed social) capital, which includes the board's links to the organization's environment [18] (e.g. customers, suppliers, investors etc.) [47]. Through their relational capital, directors provide access to resources required by the organization $[12,16,18]$, facilitate access to the commitment of outside parties [18], foster communication between the organization and its environment [18], perform a lobbying function [47] and provide legitimacy $[12,57]$.

With respect to IT governance, this board role entails two main functions: the provision of resources [7, 34, 58]; and a signaling function [34, 41]. From a resource dependency perspective, directors may leverage their relationships with multiple organizations to provide access to resources such as IT providers and capital [8, 34]. The signaling function, which may be considered part of a board's legitimating role, relates to signaling theory. This role involves establishing IT governance mechanisms at board-level, thereby signaling to the market that IT-related issues are significantly situated on the board's agenda [41], thereby strengthening the public image of the firm's IT capability [34]. In this regard, agency theory is relevant by demonstrating to the market the board's role regarding the strength of its IT oversight role [34].

It is the board's task to use its directors' ties to the external environment to facilitate provision of ITrelated resources [7, 34, 39], thereby supporting improved fulfilment of its organization's internal needs [8]. Further, by establishing IT governance 
mechanisms at the board-level, organizations demonstrate the importance that they attribute to ITrelated matters, which in turn sends a positive signal to the stock market, and therein possibly influences stock returns. In this regard, Higgs, Pinsker [41] show that negative market reactions to reported security breaches are mitigated by the presence of a technology committee, suggesting that the presence of such a committee is positively perceived by the market (i.e., a signaling function of the board).

4.1.5 Strategic control. The board's role in strategic control relates to its monitoring function, particularly reviewing strategic initiatives and overseeing the execution of strategy $[59,60]$. In accord with agency theory, this role entails boards being responsible for monitoring strategic decisions, but not their initiation and implementation [61]. From the perspective of legal theory, a board can use its fiduciary duty to control strategic decisions and evaluate these for their organizational value [62].

In the context of IT governance, IT-related goals and strategic proposals should be evaluated and monitored [6, 9]. Again, the board should evaluate management procedures, and verify whether management has established effective strategic planning processes [54]. Theoretical foundations for this role include: (1) agency theory, in relation to reducing the conflict of interest arising from the possible misalignment between IT and the business strategy [34, 63]; and (2) the resource based view of the firm related to board IT competence as board members' strategic oversight constitutes a valuable resource [40]. This board IT competence may be considered as: a dynamic capability, based on the resource based view of the firm; and a cognitive bias, based on upper echelon theory, with regard to influencing strategic choices and contributing to the organization's competitive advantage [64]. This accords with strategic choice theory in that board attributes (such as board IT competence, board size and proportion of insider directors) may influence strategic decision-making $[9,49]$.

In this regard, of primary concern is ensuring the alignment of business and IT strategy, typically phrased as strategic alignment $[6,51]$. This requires the board to ensure that IT's role aligns with the organization's overall strategy.

4.1.6 Strategic participation. In this role, the focus for boards concerns their active involvement in strategic decision-making, rather than more passive involvement in strategic control [18]. In setting the strategic direction for the organization [65], the board becomes a strategic partner with management [65]. More specifically, this role entails boards assisting in initiating strategic analysis [59, 66], as well as its formulation $[61,65,66]$, and implementation [59, 61]. As with the other service roles, perspectives here accord with stewardship theory and resource dependence theory. Importantly, by focusing on the role of boards in empowering managers, stewardship theory offers a different perspective from the agency theoretic view of the self-interested manager [47, 61]. Equally, from a theoretical pluralistic perspective, resource dependency theory suggests a critical role for boards' strategic decision-making in providing access to strategic information and reducing uncertainty through access to their network [61].

The board's strategic participation should be evident from its proactive engagement in IT-related strategic decision-making [38, 67]. With IT budgets averaging $3.64 \%$ of revenue across all industry sectors in 2018 [68] and with spending on IT-related security having increased by $10.5 \%$ in 2019 , and cloud security projected to grow $41.2 \%$ over the next five years [69], IT risk exposures require strategic consideration. In accord with corporate governance literature, IT governance researchers build on stewardship theory, to explain the need for advising management on ITrelated strategic matters [8] and on resource dependence theory as related to networking by directors for knowledge about market trends [8], and thereby facilitating strategic discussions. Other relevant theories include the resource-based view, upper echelon theory and strategic choice theory for their insights regarding the impact of board IT competence and other attributes on strategic decisionmaking.

Through their networks, directors may be well placed to garner information about the external environment [6, 39]. Here board roles include boundary spanning activities in order to inform the strategy debate [58], and thereby complement perspectives offered by executive management $[6,8$, 39]. By providing information about the external environment and thereby guiding management regarding IT-related strategic topics, the board may ensure that the organization identifies and grasps relevant opportunities $[6,70]$.

\subsection{Board-level IT governance mechanisms}

In this section, possible mechanisms to implement board-level IT governance duties are discussed. A summary of the mechanisms and their importance for each board role in governing IT is provided in Table 1. 
Table 1. Overview of board-level IT governance mechanisms for each role

\begin{tabular}{|c|c|c|c|c|c|c|}
\hline Board-level IT governance mechanism & 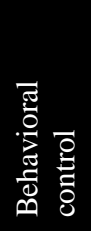 & $\begin{array}{l}\overline{0} \\
\text { : } \\
0 \\
0 \\
\text { : } \\
0 \\
0 \\
0\end{array}$ & 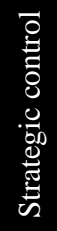 & 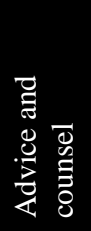 & 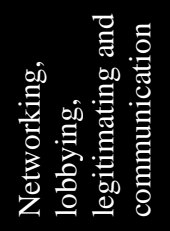 & 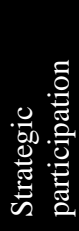 \\
\hline Board-level IT governance committee & $\mathrm{x}$ & $\mathrm{x}$ & $\mathrm{x}$ & $\mathrm{x}$ & $\mathrm{x}$ & $\mathrm{x}$ \\
\hline Board IT competence & $\mathrm{x}$ & $\mathrm{x}$ & $\mathrm{x}$ & $\mathrm{x}$ & $\mathrm{x}$ & $\mathrm{x}$ \\
\hline Include independent directors (with IT expertise) & $\mathrm{x}$ & $\mathrm{x}$ & & $\mathrm{x}$ & $\mathrm{x}$ & $\mathrm{x}$ \\
\hline CIO presenting to the board & $\mathrm{x}$ & & & $\mathrm{x}$ & & $\mathrm{x}$ \\
\hline Communication between $\mathrm{CIO}$ and board in between board meetings & $\mathrm{x}$ & & & $\mathrm{x}$ & & $\mathrm{x}$ \\
\hline CIO on the board & $\mathrm{x}$ & & & $\mathrm{x}$ & & $\mathrm{x}$ \\
\hline Long-term compensation components for CIO & $\mathrm{x}$ & & & & & \\
\hline Formal communications and review processes & & & $\mathrm{x}$ & & & \\
\hline IT scorecards or dashboards & & & $\mathrm{x}$ & & & \\
\hline Frequent IT-related briefings & & & & $\mathrm{x}$ & & \\
\hline
\end{tabular}

A certain level of IT competence is needed to support the roles of the board in IT governance. In the context of behavioral control, such competence facilitates the reduction of information asymmetry between boards and executives and thus enables better evaluation of IT decisions [44, 67]. The board's ability to provide IT-related advice and counsel is enhanced by recruiting directors with IT expertise [34]. In the context of output control, the IT experience of audit committee members should be taken into account [54]. Further, directors with IT awareness bring appropriate IT-related networks that facilitate the provision of resources in support of IT-related matters [50]. Lastly, IT competence supports the board in its strategic control $[36,50]$ and participation [8] roles. IT-related knowledge, expertise, experience, industry and educational background should be considered when recruiting directors $[34,43]$. This IT competence may relate to directors with prior executive and/or board experience in the IT sector which have gained experience at the strategic level of the organization [49]. When very specific knowledge is needed, boards could consider hiring an expert [44]. Another strategy linked to the board's IT competency is to appoint a specific director to take a leadership role with IT [36, 42]. Where boards have less IT expertise and their organizations face increasing IT intensity, CIOs may be encouraged to act in the shareholders' interests by increasing their long-term compensation [50].

Independent directors, especially those with IT expertise, play an important role in governing IT. They are typically considered responsible for monitoring $[34,40]$ and are shown to enhance the board's ability to provide IT-related advice and counsel to management [34] as they can bring insights on various
IT topics from other organizations [7, 39]. Moreover, this type of board member offers network ties [34, 49, 71] and facilitates environmental scanning as part of the board's strategic participation role [34, 72, 73]. In support of a stakeholder-oriented approach, inclusion of external members such as public policy experts, may contribute alternative viewpoints [73]. On the other hand, inside directors are essential for ensuring that firm-specific IT-related information is available to the board [9]. Therefore, including the CIO on the board may be valuable, as it enables them to directly interact and share knowledge with other board members [51]. Other strategies include regular CIO presentations to the board [74] and encouraging board members to communicate with the CIO or IT management between board meetings $[38,51]$. All these mechanisms enable the CIO to support the board in playing its behavioral control [37], advice and counsel [51] and strategic participation $[8,38]$ roles.

Researchers advise the establishment of a boardlevel committee with IT governance responsibilities for all six roles discussed above [34, 39-41, 44, 45, 58, 75]. Depending on the type of organization, an audit committee $[36,37]$ or the risk management committee [37] may assume similar responsibilities, providing they possess adequate IT-related competency [72].

Providing strategic oversight requires effective communication to and by the board about the strategic direction and progress of IT [38, 76]. Such communication may be facilitated through formal communication and review processes, as well as by using scorecards or dashboards [38]. Lastly, the board can require management to frequently brief them on IT related matters in support of their advising role [8]. 


\section{Discussion}

This study seeks to clarify current understanding about the role of an organization's board in IT governance. As detailed in Section 1, the two research questions framing our inquiry concern what these roles are and how these roles may be implemented. By drawing on literature concerned with corporate governance in order to develop a coding frame regarding the roles required for boards of directors in executing corporate governance, we are able to apply these findings to our conceptual content analysis of a selected sample of literature concerned with boardlevel IT governance and thereby theoretically review boards' IT governance roles. These findings are now discussed more specifically below.

Firstly, with regard to IT governance, we find that the board has five main roles, namely: behavioral control; strategic control; advice and counsel; networking, lobbying, legitimating and communication; and strategic participation. Little information was identified regarding the output control role, which from a corporate governance perspective, theoretically relates to controlling an organization's outputs, not only in the interest of shareholders, but for all organizational stakeholders. An explanation for this lack of evidence may relate to either the role being less important in the context of IT, or being underresearched in IT governance literature. As one of the main elements of the output control role, transparency in IT governance, has received little attention in academic research [77], it will not be included hereafter in the discussion.

In terms of the definition of IT governance adopted for the purposes of this study, IT governance is fundamentally concerned with both the creation and protection of IT business value [4]. Here, a number of board roles are crucial in creating IT business value. Strategic control and participation are important board roles in ensuring strategic oversight. The behavioral control role almost solely focusses on the protection of IT business value. Both advice and counsel, and the networking, lobbying, legitimating and communication roles address creating and protecting IT business value. Given that purely focusing on value protection is insufficient, the board's focus should go beyond controlling management behavior. This finding accords with the study of Turel et al. [6] who identified detrimental effects from an authoritarian governance style that focuses solely on monitoring aspects of governance. Nevertheless, a single focus on value creation is not beneficial either, meaning the board should go further than just implementing strategic roles. In summary, it is important that boards engage with the breadth of their roles in order to optimally contribute to IT governance, thereby supporting both the protection and creation of IT business value.

The second research question relates to how these board roles may be implemented. Whilst various IT governance mechanisms were identified, three recur for each role: board IT competence, including independent directors (with IT expertise) and a boardlevel IT governance committee. Given these findings, such mechanisms could be considered as a minimum requirement for each board. Indeed, it seems evident that a minimum level of IT competence at the boardlevel is required for a board to adequately perform IT governance duties. Mechanisms to support this include that appointments to the board should be considered in terms of directors' IT experience gained at a strategic level, such as through prior board experience or executive level positions held in IT organizations and/or as a CIO or CTO [49]. As our findings show that board roles require governing IT at a strategic level, rather than dealing with the technical details, a technical degree may be less valuable than strategic IT experience. Interestingly, Vincent, Higgs [44] report that whilst board IT competence positively influences IT risk management maturity, board involvement is more important, suggesting that simply attracting ITcompetent board members is insufficient. Indeed, our results show that boards should contribute to governing IT by performing a range of roles, with IT competence being only one mechanism to support performance of these duties.

Many of the identified IT governance mechanisms relate to providing IT-related information to the board e.g., meetings with the $\mathrm{CIO}$, formal communications, review processes and frequent IT-related briefings occur. In providing this information, the board is heavily reliant on executive management, with the CIO playing a pivotal role. Through mechanisms such as presentations to the board or communicating with the board between board meetings, the CIO can bridge between the board and the organization regarding ITrelated matters. This communication is shown to be challenged, as some findings show that CIOs and CTOs are reluctant to allow board interference in their IT management roles [38]. In this regard, research shows that management is more reluctant to share information when boards emphasize monitoring, whereas boards who adopt an advisory role stimulate information exchange, as management expects this will result in better advice [11]. Accordingly, to receive necessary information on IT-related matters, it appears crucial for a board to effectively perform its advice and 
counsel role. As findings show that receiving ITrelated information is especially important for behavioral control and strategic control, we argue that this advice and counsel role will indirectly support the board in performing these control roles.

\section{Limitations and future research}

By building upon academic literature related to corporate governance and IT governance, this research offers opportunities for future research to extend theoretical findings by incorporating insights from practice. Further, given our limited findings concerning a board's output control role in IT governance, future research could investigate whether this role is relevant, or whether its purpose and value are yet to be identified. Finally, building on studies showing that a board's governance style moderates the effect of board-level IT governance on firm performance, it is timely to investigate a board's roles here and how this moderating effect actually materializes.

\section{Conclusion and implications}

While prior studies have briefly touched upon board duties with regard to IT, this research took a step further in outlining the roles of the board in the context of IT governance and possible ways of implementing them, to develop a more concrete understanding of board-level IT governance. Whilst we derive our findings by building upon the more mature domain of corporate governance, at the same time our results inform the corporate governance literature. Here, as digital transformation is a key factor contributing to organizations' growing complexity [30], our findings related to the roles that boards should enact regarding IT governance may relatedly inform corporate governance research regarding board roles regarding IT risk management. From a practitioner perspective, our study provides clear guidance concerning how boards can contribute to governing IT. Specifically, we define their different roles, including examples of specific tasks and guidance regarding ways to implement these roles.

\section{References}

[1] De Haes, S. and W. Van Grembergen, An Exploratory Study into IT Governance Implementations and its Impact on Business/IT Alignment. Information Systems Management, 2009. 26(2): p. 123-137.

[2] Wilkin, C.L. and R.H. Chenhall, A review of IT governance: A taxonomy to inform accounting information systems. Journal of Information Systems, 2010. 24(2): p. 107-146.

[3] Wilkin, C.L. and R.H. Chenhall, Information Technology Governance: Reflections on the Past and Future Directions. Journal of Information Systems, 2019.

[4] De Haes, S., et al., Enterprise Governance of Information Technology: Achieving Alignment and Value in Digital Organizations. 3 ed. Management for Professionals. 2020, Switzerland: Springer. 204.

[5] Caluwe, L. and S. De Haes, Board Level IT Governance: A Scoping Review to Set the Research Agenda. Information Systems Management, 2019. 36(3): p. 262-283.

[6] Turel, O., P. Liu, and C. Bart, Board-Level Information Technology Governance Effects on Organizational Performance: the Roles of Strategic Alignment and Authoritarian Governance Style. Information Systems Management, 2017. 34(2): p. 117-136.

[7] Turel, O., P. Liu, and C. Bart, Is board IT governance a silver bullet? A capability complementarity and shaping view. International Journal of Accounting Information Systems, 2019. 33: p. 32-46.

[8] Turel, O. and C. Bart, Board-level IT governance and organizational performance. European Journal of Information Systems, 2014. 23(2): p. 223-239.

[9] Jewer, J. and K.N. McKay, Antecedents and Consequences of Board IT Governance: Institutional and Strategic Choice Perspectives. Journal of the Association for Information Systems, 2012. 13(7): p. 581-617.

[10] Liu, P., O. Turel, and C. Bart, Board IT Governance in Context: Considering Governance Style and Environmental Dynamism Contingencies. Information Systems Management, 2019. 36(3): p. 212-227.

[11] Adams, R.B. and D. Ferreira, A theory of friendly boards. The Journal of Finance, 2007. 62(1): p. 217-250.

[12] Johnson, J.L., C.M. Daily, and A.E. Ellstrand, Boards of directors: A review and research agenda. Journal of management, 1996. 22(3): p. 409-438.

[13] Sundaramurthy, C. and M. Lewis, Control and collaboration: Paradoxes of governance. Academy of management review, 2003. 28(3): p. 397-415.

[14] OECD, G20/OECD Principles of Corporate Governance. 2015, Paris: OECD Publishing.

[15] Roberts, J., T. McNulty, and P. Stiles, Beyond agency conceptions of the work of the non-executive director: Creating accountability in the boardroom. British journal of management, 2005. 16(s1).

[16] Daily, C.M., D.R. Dalton, and A.A. Cannella, Corporate governance: Decades of dialogue and data. Academy of management review, 2003. 28(3): p. 371-382. 
[17] Eisenhardt, K.M., Agency theory: An assessment and review. Academy of management review, 1989. 14(1): p. 57-74.

[18] Hillman, A.J. and T. Dalziel, Boards of directors and firm performance: Integrating agency and resource dependence perspectives. Academy of Management review, 2003. 28(3): p. 383-396.

[19] Huse, M., Accountability and creating accountability: A framework for exploring behavioural perspectives of corporate governance. British Journal of Management, 2005. 16(s1): p. S65-S79.

[20] Shleifer, A. and R.W. Vishny, A survey of corporate governance. The journal of finance, 1997. 52(2): p. 737-783.

[21] Li, C., J.-H. Lim, and Q. Wang, Internal and external influences on IT control governance. International Journal of Accounting Information Systems, 2007. 8(4): p. 225-239.

[22] The Institute of Internal Auditors (IIA), International Standards for the Professional Practice of Internal Auditing (Standards). 2016.

[23] Institute of Directors in Southern Africa (IoDSA), King IV Report on Corporate Governance for South Africa 2016. 2016.

[24] ISO/IEC, ISO/IEC Standard 38500: Information technology - Governance of IT for the organization. 2015.

[25] Steinbart, P.J., et al., The influence of a good relationship between the internal audit and information security functions on information security outcomes. Accounting, Organizations and Society, 2018. 71: p. 15-29.

[26] Abbasi, A., S. Sarker, and R.H. Chiang, Big data research in information systems: Toward an inclusive research agenda. Journal of the Association for Information Systems, 2016. 17(2): p. 3.

[27] PWC, Blockchain is here. What's your next move? 2020.

[28] Ponemon, 2018 Cost of a Data Breach Study: Global Overview. 2018.

[29] Stafford, T., et al., The Role of Accounting and Professional Associations in IT Security Auditing: An AMCIS Panel Report. Communications of the Association for Information Systems, 2018. 43(1): p. 27.

[30] Huse, M., Value-Creating Boards: Challenges for Future Practice and Research (Elements in Corporate Governance). 2018, Cambridge: Cambridge University Press.

[31] Zahra, S.A. and J.A. Pearce, Boards of directors and corporate financial performance: A review and integrative model. Journal of management, 1989. 15(2): p. 291-334.

[32] Schreier, M., Qualitative content analysis in practice. 2012: Sage Publications.

[33] Adams, R.B., B.E. Hermalin, and M.S. Weisbach, The role of boards of directors in corporate governance: A conceptual framework and survey.
Journal of Economic Literature, 2010. 48(1): p. 58107.

[34] Benaroch, M. and A. Chernobai, Operational IT failures, IT value-destruction, and board-level IT governance changes. MIS quarterly, 2017. 41(3): p. 729-762.

[35] Valentine, E. and G. Stewart, Enterprise Business Technology Governance: Three Competencies to Build Board Digital Leadership Capability, in 2015 48th Hawaii International Conference on System Sciences, T.X. Bui and R.H. Sprague, Editors. 2015: Kauai, HI. p. 4513-4522.

[36] Trites, G., Director responsibility for IT governance. International Journal of Accounting Information Systems, 2004. 5(2): p. 89-99.

[37] Posthumus, S., R. von Solms, and M. King, The board and IT governance: The what, who and how. South African Journal of Business Management, 2010. 41(3): p. 23-32.

[38] Andriole, S.J., Boards of directors and technology governance: The surprising state of the practice. Communications of the Association for Information Systems, 2009. 24(1): p. 22.

[39] Turel, O., P. Liu, and C. Bart, Board-Level IT Governance. IT Professional, 2019. 21(2): p. 5865.

[40] Price, J.B. and N. Lankton, A Framework and Guidelines for Assessing and Developing BoardLevel Information Technology Committee Charters. Journal of Information Systems, 2018. 32(1): p. 109-129.

[41] Higgs, J.L., et al., The relationship between boardlevel technology committees and reported security breaches. Journal of Information Systems, 2016. 30(3): p. 79-98.

[42] Parent, M. and B.H. Reich, Governing Information Technology Risk. California Management Review, 2009. 51(3): p. 134-+.

[43] Trautman, L.J. and K. Altenbaumer-Price, The board's responsibility for information technology governance. J. Marshall J. Computer \& Info. L., 2010. 28(3): p. 313.

[44] Vincent, N.E., J.L. Higgs, and R.E. Pinsker, Board and Management-Level Factors Affecting the Maturity of IT Risk Management Practices. Journal of Information Systems, 2019. 33(3): p. 117-135.

[45] Read, T.J., Discussion of director responsibility for IT governance. International journal of accounting information systems, 2004. 5(2): p. 105-107.

[46] Baysinger, B. and R.E. Hoskisson, The composition of boards of directors and strategic control: Effects on corporate strategy. Academy of Management review, 1990. 15(1): p. 72-87.

[47] Kim, Y. and A.A. Cannella Jr, Toward a social capital theory of director selection. Corporate Governance: An International Review, 2008. 16(4): p. 282-293.

[48] Brickley, J.A. and J.L. Zimmerman, Corporate governance myths: comments on Armstrong, Guay, and Weber. Journal of Accounting and Economics, 2010. 50(2-3): p. 235-245. 
[49] Van Peteghem, M., et al. Board IT competence and firm performance. in Fortieth International Conference on Information Systems, December 1518, 2019, Munich, Germany. 2019.

[50] Yayla, A.A. and Q. Hu, The effect of Board of directors' IT awareness on CIO compensation and firm performance. Decision Sciences, 2014. 45(3): p. 401-436.

[51] Coertze, J. and R. von Solms. The Board and CIO: The IT Alignment Challenge. in 2014 47th Hawaii International Conference on System Sciences. 2014. Waikoloa, HI.

[52] Jo, H. and M.A. Harjoto, Corporate governance and firm value: The impact of corporate social responsibility. Journal of business ethics, 2011. 103(3): p. 351-383.

[53] Frias-Aceituno, J.V., L. Rodriguez-Ariza, and I.M. Garcia-Sanchez, The role of the board in the dissemination of integrated corporate social reporting. Corporate social responsibility and environmental management, 2013. 20(4): p. 219233.

[54] Butler, R. and M.J. Butler, Beyond King III: Assigning accountability for IT governance in South African enterprises. South African Journal of Business Management, 2010. 41(3): p. 33-45.

[55] Best, P. and S. Buckby. Development of a Board IT Governance (ITG) Review Model. in 2007 Accounting \& Finance Association of Australia and New Zealand Conference (AFAANZ 2007). 2007. Gold Coast, Australia.

[56] Pfeffer, J. and G.R. Salancik, The external control of organizations: A resource dependence approach. NY: Harper and Row Publishers, 1978.

[57] Hillman, A.J., A.A. Cannella, and R.L. Paetzold, The resource dependence role of corporate directors: Strategic adaptation of board composition in response to environmental change. Journal of Management studies, 2000. 37(2): p. 235-256.

[58] Nolan, R. and F.W. McFarlan, Information technology and the board of directors. Harvard Business Review, 2005. 83(10): p. 96-+.

[59] Barroso-Castro, C., M.M. Villegas-Periñan, and M. Dominguez, Board members' contribution to strategy: The mediating role of board internal processes. European research on management and business economics, 2017. 23(2): p. 82-89.

[60] Rindova, V.P., What corporate boards have to do with strategy: A cognitive perspective. Journal of management studies, 1999. 36(7): p. 953-975.

[61] Pugliese, A., et al., Boards of directors' contribution to strategy: A literature review and research agenda. Corporate Governance: An International Review, 2009. 17(3): p. 292-306.

[62] Lan, L.L. and L. Heracleous, Rethinking agency theory: The view from law. Academy of management review, 2010. 35(2): p. 294-314.

[63] Posthumus, S. and R. von Solms. Agency theory: Can it be used to strengthen IT governance? in 23rd IFIP International Information Security Conference. 2008. Milano, Italy.

[64] Héroux, S. and A. Fortin, The moderating role of IT-business alignment in the relationship between IT governance, IT competence, and innovation. Information Systems Management, 2018. 35(2): p. 98-123.

[65] Judge, W.Q. and C.P. Zeithaml, Institutional and strategic choice perspectives on board involvement in the strategic decision process. Academy of management Journal, 1992. 35(4): p. 766-794.

[66] Ingley, C.B. and N.T. Van der Walt, The strategic board: The changing role of directors in developing and maintaining corporate capability. Corporate Governance: An International Review, 2001. 9(3): p. 174-185.

[67] Valentine, E. and G. Stewart. Director competencies for effective enterprise technology governance. in Proceedings of the 24th Australasian Conference on Information Systems (ACIS 2013). 2013. Melbourne, Australia.

[68] Deloitte CIO Insider. Reinventing tech finance: The evolution from IT budgets to technology investments. 2020.

[69] Gartner, Gartner says IT Spending to Grow 3.7\% in 2020. 2020.

[70] Bart, C. and O. Turel, IT and the board of directors: An empirical investigation into the "governance questions" Canadian board members ask about IT. Journal of Information Systems, 2010. 24(2): p. 147-172.

[71] Kambil, A. and H.C. Lucas, The board of directors and the management of information technology. Communications of the Association for Information Systems, 2002. 8(1): p. 26.

[72] Ako-Nai, A. and A.M. Singh, Information technology governance framework for improving organisational performance. South African Journal of Information Management, 2019. 21(1): p. 1-11.

[73] Raghupathi, W., Corporate governance of IT: A framework for development. Communications of the ACM, 2007. 50(8): p. 94-99.

[74] Mähring, M., The role of the board of directors in IT governance: A review and agenda for research, in AMCIS 2006 Proceedings. 2006: Acapulco, Mexico. p. 377.

[75] Premuroso, R.F. and S. Bhattacharya, Is there a relationship between firm performance, corporate governance, and a firm's decision to form a technology committee? Corporate Governance: An International Review, 2007. 15(6): p. 1260-1276.

[76] Kuruzovich, J., G. Bassellier, and V. Sambamurthy. IT governance processes and IT alignment: Viewpoints from the board of directors. in 45th Hawaii International Conference on System Science (HICSS). 2012. Kauai, HI: IEEE.

[77] Joshi, A., L. Bollen, and H. Hassink, An empirical assessment of IT governance transparency: Evidence from commercial banking. Information Systems Management, 2013. 30(2): p. 116-136. 